\title{
Spatio-Temporal Distribution of Chlorophyll-a Using Multitemporal Landsat Image and Ground Check in Segara Anakan Lagoon
}

\author{
Rose Dewi ${ }^{1,3^{*}}$, Muhammad Zainuri ${ }^{2,4}$, Sutrisno Anggoro ${ }^{1}$, \\ Tjahjo Winanto ${ }^{3}$, Hadi Endrawati ${ }^{5}$ \\ ${ }^{1}$ Coastal Resources Management Doctoral Program, \\ Fisheries and Marine Science Department, Diponegoro University \\ ${ }^{2}$ Departement of Oceanography, Fisheries and Marine Science Department, Diponegoro University \\ ${ }^{3}$ Fisheries and Marine Science Department, Jenderal Soedirman University \\ ${ }^{4}$ Centre of Excellent Mitigation of Natural Disaster and Coastal Rehabilitation, Diponegoro University \\ ${ }^{5}$ Fisheries and Marine Science Department, Diponegoro University
}

\begin{abstract}
Segara Anakan lagoon (SAL) is a dynamic estuary, downstream of several rivers in Citanduy watershed, humid tropical climate and influenced monsoon, conditions that cause waters to fluctuate. There are influence of natural and anthropogenic factors that impact on the increase of aquatic organic matter, as phytoplankton indicator biota able to show its tolerance characterized by fluctuation of chlorophyll content a. The purpose of this research is to know the spatio-temporal distribution of chlorophyll- a SAL region. The chlorophyll- a measurement method uses multitemporal landsat images and field measurements. The temporal approach (time series) during 2016 refers to the monsoon wind pattern and spatially on seven different stations of ecological characteristics. Data processing using ER Mapper 7.0 software and the preparation of thematic data with Arc GIS software. Testing data accuracy using regression analysis. The results of chlorophyll-a recording of landsat images ranged from $3,213-3,703\left(\mathrm{mg} / \mathrm{m}^{3}\right)$ and field measurements from 0.01 to $5.06\left(\mathrm{mg} / \mathrm{m}^{3}\right)$. Temporally transitional seasons and on spatial approaches, stations with anthropogenic characteristics have the highest chlorophyll content. The condition is supported by the accumulation of aquatic organic materials, high rainfall and upwelling phenomenon. Test of accuracy pertained high, shown with value of $r=0,94$ at equation $y=-30.07 x^{2}+217.0 x-387.0, R^{2}=0.894$ with regression characteristic is polynomial. The high accuracy value in the equation, shows that the SAL area algorithm can be applied to obtain chlorophyll content data in the field in the previous year with the support of satellite image data in that year.
\end{abstract}

\section{Introduction}

Segara Anakan Lagoon (SAL) is geographically located at $7^{\circ} 35^{\prime \prime}-7^{\circ} 46^{\prime \prime}$ LS and $108^{\circ} 45^{\prime \prime}-109^{\circ} 01 "$ BT, covering 14.221,8 ha, in district of Kampung Laut, Cilacap Regency, Central Java. SAL is located in the southern of coastal area of Java Island. The existence of Nusa Kambangan Island as a barrier, disconnects the SAL from the Indian Ocean. The lagoon is connected by two inlets (canals): Eastern Pelawangan (Eastern outlet) on the East Nusakambangan island and West Pelawangan (Western outlet). Its moist tropical climate and influence from monsoon causes the fluctuated water. The form changes happening up to now occured through various stages of environmental change. This has been caused by the SAL area does not stand alone. There are natural and anthropogenic factors, especially in the west affecting in the ecological changes of the region [1], [3], [6].

The naturally influence factor resulted in the lagoon having shallow depth $(<2 \mathrm{~m})$, as an estuary which receives freshwater flow in high quantity especially during rainfall, coming along with suspended sediment derived from river Citanduy as main river and largest Citanduy watershed besides river Cimeneng, river Cikonde, river Cibereum.

${ }^{1}$ Corresponding author: rose.83unsoed@gmail.com

(C) The Authors, published by EDP Sciences. This is an open access article distributed under the terms of the Creative Commons Attribution License 4.0 (http://creativecommons.org/licenses/by/4.0/). 
They are only the parts of the lagoon leading to the Indian Ocean that has depth $(10 \mathrm{~m}<)$ [12]. Another side, the anthropogenic effect is due to the increase of comparable population to the increasing of the use of SAL land and area around Activities in Citanduy Watershed are : fishery, agriculture, industry and domestic (settlement). This gave higher pressure on the lagoons with water bodies decline and the accumulation of organic matter on the lagoon[1], [7], [12].

According to Parslow, et al., [18] and Jennerjahn, et al., [12] the high-low organic materials are converted to the limiting factor of the distribution and quantity of chlorophyll-a phytoplankton, subsequently affecting its abundance. Generally, high-chlorophyll a in coastal waters as the supply of organic material from the mainland through river runoff and vice versa tends to decrease in offshore areas [8], [4]. Furthermore, Yuwono, et al., (2007) and Jennerjahn, et al., [13] chlorophyll -a SAL region is averaged from 1.8 to $6.1 \mu \mathrm{g} / \mathrm{L}$. Chlorophyll-a is the main photosynthetic pigment in phytoplankton, as the primary biota of the recipients of the effects of demonstrated aquatic ecological changes through adaptation to the increase in organic material [14], [21]; [2].

Laboratory measurement of chlorophyll on the field (Ground check) in large waters requires the points of multiple station, relatively long time and less cost effeciency. Further remote sensing methods using satellite imagery is proposed a variety of conveniences. This technology enables to provide information quickly so it can be observed the phenomenon of waters in the range of spatial and dynamic range [9], [5]. One example of remote sensing applications that can detect distribution patterns and abundance of phytoplankton is estimated through chlorophyll-a by using landsat satellite imagery. The use of satellite of imagery will be obtained by distribution profile and chlorophyll quantity in real time, because the data information based on spectral value of object is recorded by sensor landsat [16]. Chlorophyll- a measurement ground check is to verify data from satellite image mapping. Furthermore, the accuracy test can be undergone to determine the extent to which the image can provide chlorophyll a water information. Accuracy is done by comparing the value of chlorophyll of landsat image recording with field measurement (Ground check) [20]. The purpose of this research is to know the spatio-temporal distribution of chlorophyll content of Western SAL region obtained through landsat multitemporal landscaping and ground check.

\section{Materials and Methods}

The measurement of chlorophyll content was carried out by using multitemporal landsat imagery and Ground check, with a year-long temporal (time series) approach (2016) based on monsoon representation. According to Nontji [15], based on Meteorological and Oceanographic data, Indonesian waters are affected by the monsoon :

- West Season : Desember - February

(representing February and December).

- Transition Season 1: March - May

(representing Mei).

- East Season : June - August

(representing Juli)

- Transition Season II: September-November

(Representing October).

The temporal approach is used as a reference time of data collection of chlorophyll-a phytoplankton in the field ground check. Furthermore, spatial approach is carried out by selecting the seven research stations that have ecologically characteristic difference of SAL area. It is aimed to evaluate the ecological influence (response) on the impact of natural factors in the station $(2,3,4,6)$ and the influence of community anthropogenic activities around the lagoon at the station $(1,5,7)$. Further description of the spatial approach is shown in (Table.1). 
Tabel. 1 The sampling characteristic by spacial approach of phytoplanton in Segara Anakan Lagoon, District of Cilacap.

\begin{tabular}{llcc}
\hline \multicolumn{1}{c}{ Characteristics } & \multicolumn{2}{c}{ Ordinate } \\
\hline 1 & TPI and Majingkak Port & $108^{\circ} 48^{\prime} 02.4^{\prime \prime} \mathrm{BT}$ & $07^{\circ} 40^{\prime} 27.6^{\prime \prime} \mathrm{LS}$ \\
2 & $\begin{array}{l}\text { Gate Border (Pelawangan Barat) of SAL borderlining } \\
\text { with Hindia Ocean }\end{array}$ & $108^{\circ} 46^{\prime} 56.7^{\prime \prime} \mathrm{BT}$ & $07^{\circ} 41^{\prime} 59.0^{\prime \prime} \mathrm{LS}$ \\
3 & Gate of Cikonde dan Cimeneng river & $108^{\circ} 49^{\prime} 47.9^{\prime \prime} \mathrm{BT}$ & $07^{\circ} 40^{\prime} 34.6^{\prime \prime} \mathrm{LS}$ \\
4 & The Area of Mangroves & $108^{\circ} 51^{\prime} 36.5^{\prime \prime} \mathrm{BT}$ & $07^{\circ} 41^{\prime} 44.9^{\prime \prime} \mathrm{LS}$ \\
5 & Kampung laut settlement & $108^{\circ} 52^{\prime} 14.0^{\prime \prime} \mathrm{BT}$ & $07^{\circ} 42^{\prime} 19.5^{\prime \prime} \mathrm{LS}$ \\
6 & Conservative tourism "Mina" "Ujung Alang, district & $108^{\circ} 52^{\prime} 45.4^{\prime \prime} \mathrm{BT}$ & $07^{\circ} 42^{\prime} 55.4^{\prime \prime} \mathrm{LS}$ \\
& of Kampung Laut & $108^{\circ} 48^{\prime} 56.0^{\prime \prime} \mathrm{BT}$ & $07^{\circ} 41^{\prime} 01.0^{\prime \prime} \mathrm{LS}$ \\
\hline
\end{tabular}

\subsection{The laboratorially content measurement of chlorophyll-a in Ground check}

Ground check of chlorophyll a is done simultaneously as the satellite passing through the SAL region. The analysis used theory stated by Hutagalung, et al., [11]. Water samples for the determination of phytoplankton chlorophyll content were started by filtration using Whatman GF / C papers with a diameter of $47 \mathrm{~mm}$, placed on a filter holder (dampened with aquades, to prevent the filtered paper from attaching), the filter glass was installed. Put $500 \mathrm{ml}$ of water sample. Filtering assisted suction pump $\pm 30 \mathrm{~cm} \mathrm{Hg}$, until until the pores can not be seen. pori filter mampat. The filtrated filter was extracted by dissolving chlorophyll at $10 \mathrm{~mL}$ aceton by $90 \%$ and placed in a $15 \mathrm{~mL}$ tube, the process is carried out in a space that is impermeable to light. Followed by centrifugation process (filtrate on $15 \mathrm{~mL}$ tube) with $4000 \mathrm{rpm}$ rotation, 30 mins to form natan (in the form of rest of filter paper carried and deposited based on test tube) and supernatant (in the form of chlorophyll solution). The supernatant is transferred into cuvet to be measured for absorbance using a spectrophotometer of the DMS-90 Uv.Vis model Variant. at $750 \mathrm{~nm}, 664 \mathrm{~nm}, 647$ $\mathrm{nm}$, and $630 \mathrm{~nm}$ wavelengths. The absorption value is used to calculate chlorophyll-a. Calculation of chlorophyll content according to Hutagalung, et al., [11], calculated by the following formula:

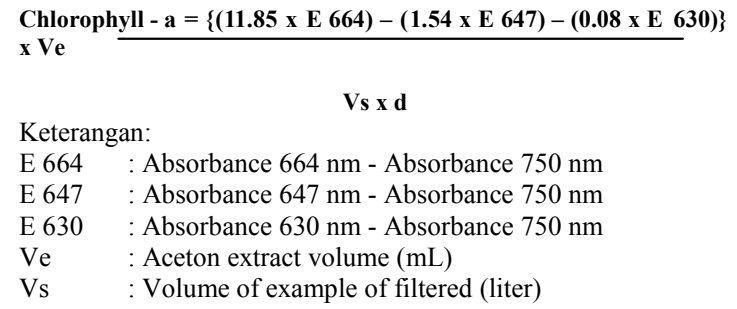

\subsection{The determination of chlorophyll- a with analysis of Landscape image Landsat satellite multitemporal}

The analysis is done by the following stages:

- Landsat image 8 data was obtained from the download on the site: http://earthexplorer.usgs.gov/ on the process of satellite image data download landsat masking image by using cirrus band for the freed displayed image the cloud . The process of digital satellite data processing 8 , is using the manual provided by the USGS http://landsat.usgs.gov/landsat8 using product.php.

- The correction of Geometric is then performed, with the method map to map reprojection method, is aimed to provide the actual geographic position in the image. Geoographic coordinate system NUTM, changed to SUTM for the used image is the region of Central Java.

- Radiometric Correction with Digital Number (DN) conversion to TOA Reflectance:

- Convert TOA Reflectance to a value of Chlorophyll-a. 
The algorithm used to chlorophyll-a :

$$
c=0,2818 \times\left\{\frac{B 5+B 6}{B 4}\right\}^{3 / 497}
$$

Explaination :

$\mathrm{C}=$ Consentration of chlorophyll-a $\left(\mathrm{mg} / \mathrm{m}^{3}\right)$

B4 (i1) $=$ Value of reflectansikanal 4 Landsat 8

B5 (i2) = Value of reflectansikanal 5 Landsat 8

B6 (i3) = Value of reflectansikanal 6 Landsat 8

Data processing uses ER Mapper 7.0 software, data that has been previously downloaded with tif format, then performed the merger of the band and stored in ers format (er mapper raster dataset). The data has been processed to display thematic data using Arc GIS software with output in image format (Jpeg). Based on image data in the form of digital value range and interpretation of multitemporal landsat image processing results, it can be displayed visually for further discussed descriptively [20].

2.3 The Accuracy of Cholophyl a content between the results of Landsat satellite multitemporal imagery measurements and the Ground Check (SAL) area content

After obtaining the results of measurement of chlorophyll a between the satellite landsat and field measurements (Ground check) then the mapping accuracy was conducted [16]. The mapping accuracy test is obtained from the output of regression equation between field data and landsat image data using regression equation which is adjusted to the data characteristic obtained [20]:

Liner regression

Orde polynomial 2

Orde polynomial 3

$$
\begin{aligned}
& : y=a+b x \\
& : y=a+b x^{2}+b 1 x \\
& : y=a+b x^{3}+b 1 x^{2}+b 2 x
\end{aligned}
$$

The close relationship between the two variables $(\mathrm{X})$ and $(\mathrm{Y})$ that can be seen from the correlation coefficient $(\mathrm{r})$ is obtained from the root of the coefficient of determination $\left(\mathrm{R}^{2}\right)$. The value of $\mathrm{r}$ ranges from 0 to 1 , if the result is close to +1 the relationship among the two variables is strong or there is a high correlation between the two and their respects that is close to zero, the connection is very weak [22].

\section{Result and Discussion}

3.1 The chlorophyll- a content during the research done in 2016 based on Landsat satellite multitemporal imagery measurements and the ground check.

The analysis of chlorophyll content parameter of Segara Anakan lagoon area in 2016 uses multitemporal landscape satellite image recording (Landsat 8) (Figure 1). Image recording while crossing the SAL area is conducted 5 times during 2016, the reference is expected to represent the picture of each season period (monsoon). Landscape image data was taken on the west season (7 February), transition season I (May 6), east season (July 25), transitional season II (October 13) and west season (December 16). The quantitative results of chlorophyll a-mark as a result of TOA reflectance conversion of Landsat imagery ranged from $3.213-3.703\left(\mathrm{mg} / \mathrm{m}^{3}\right)$. Especially for western season data (February), multitemporal landsat images can not support an idea of the concentration of chlorophyll content a, this is caused by the condition of the SAL area is covered by the thickness of the cloud. Allegedly in February 2016, it has a high level of rainfall. Based on the data served from Meteorology, Climatology and Geophysics Agency (BMKG) Cilacap Regency, that in February 2016 rainfall reached $437 \mathrm{~mm}$, which is the highest rainfall conditions occurred in February during the last five years. 


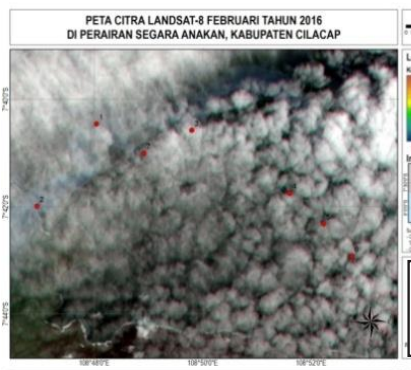

PETA KLOROFLLA OKTOBER TAHUN 2016
DI PERAIPAN SEGARA ANAKAN, KABUPATEN CILACAP

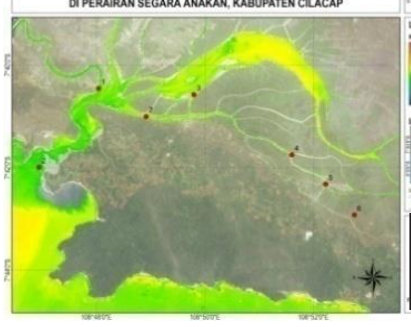

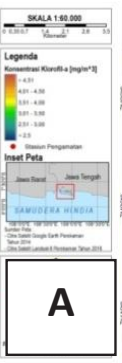

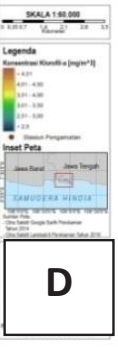

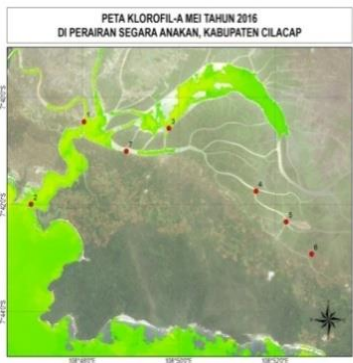
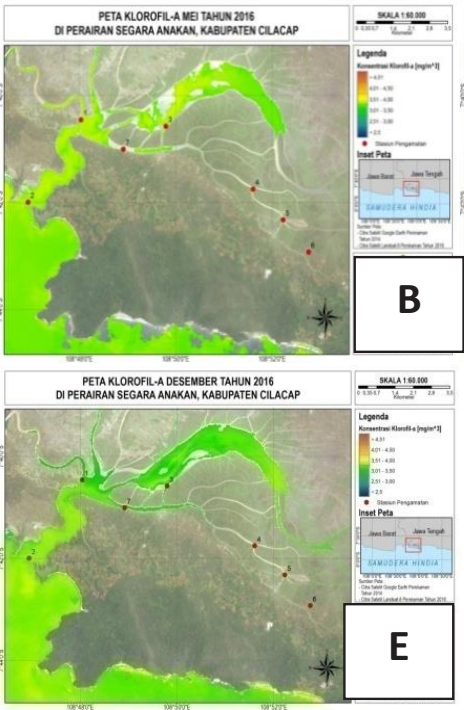

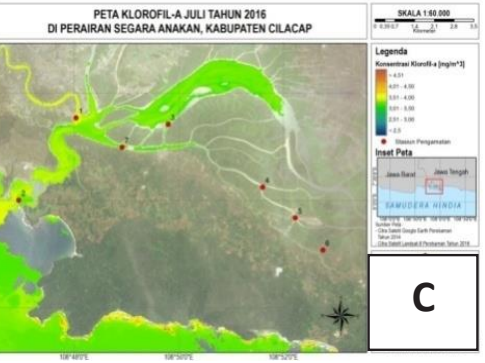

Legend

Chlorophyll- $a$

concentration $\left(\mathrm{mg} / \mathrm{m}^{3}\right)$

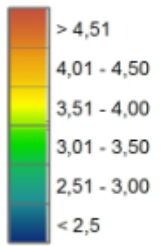

Fig. 1 Spasio-temporal chlorophyll-a content based on the result of Landsat satellite multitemporal Image Record : A) West season (February); B) Transition season I (May); C) East season (July); D) Transition season II (October); E) West season (December).

Based on the qualitative analysis, the visualization of landsat image recording and quantitative analysis of chlorophyll-a values shows that the transition season I (May) is the highest chlorophyll- a season with a range of $3.50 \pm 0.09 \mathrm{mg} / \mathrm{m}^{3}$. This is in line with the results of the highest temporal phytoplankton a bundance measurements occurred this season, with a quantity of $(9956,57 \pm 5300,23)$ indv / L. The distribution and abundance of phytoplankton can be estimated from its chlorophyll content through remote sensing imagery technology. Landsat imagery can provide the information of waters data according to spectral object value recorded by landsat cencor.

Nontji (2008) added that the transition season (transition) pattern direction and wind power is not stabilized, but generally, relatively, calm water conditions. Suspected phytoplankton can process photosynthesis optimally. The results of Landsatographic recording in this study strengthen the sensing results, which show that phytoplankton biomass can be described in units of chlorophyll $\left(\mathrm{mg} / \mathrm{m}^{3}\right)$.
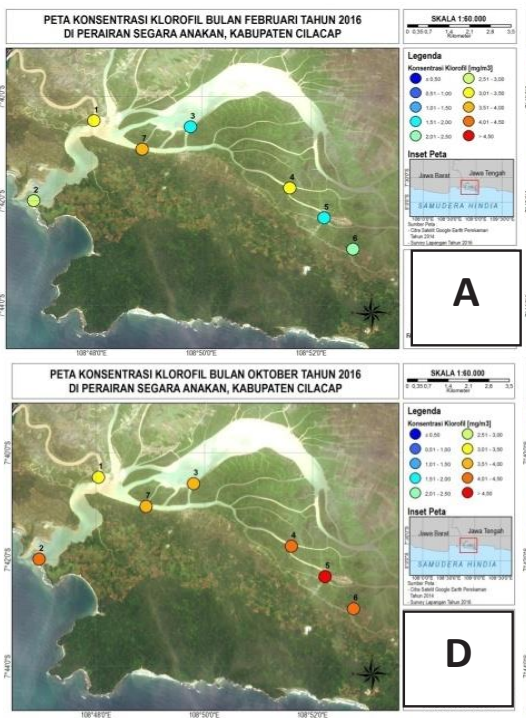

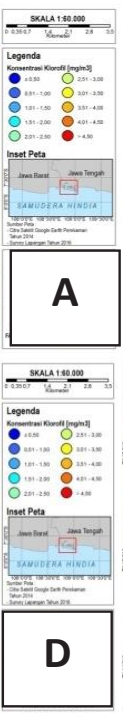

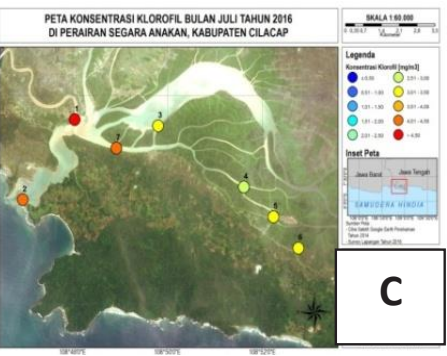
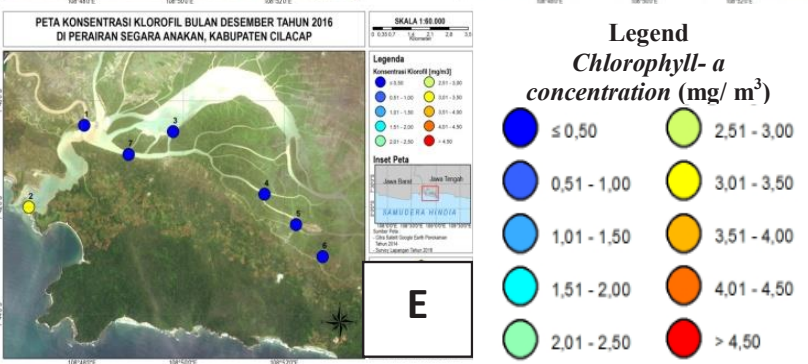
Fig. 2 Spasio-temporal chlorophyll-a content based on the result of Ground-check in Segara anakan lagoon area 2016: A) West season (February); B) Transition season I (may); C) East season (July); D) Transition season II (October); E) West season (December).

Furthermore, the highest quantity of chlorophyll-a content is followed by east season and transition II and the lowest is in west season (December). Overall it is recognised that SAL waters during 2016 are strongly influenced by high rainfall, which started in the east season (June-August) and increased again during the second transition season (September-November). Rainfall zenith occurred in October, further, It declined in November and December along with a decrease of chlorophyll-a. Despite the prevailing conditions, that in the east of the wind blows from east to west and marks the beginning of the dry season, the opposite condition in the west season that marks the rainy season.

Rainfall pattern, is a factor of fluctuation control of organic material, which was significantly influencing to fluctuation of $\mathrm{N}$ and $\mathrm{P}$ as barrier of waters affecting distribution and quantity of chlorophyll-a. [19],[14], [13]. On the other hand, the result of laboratory analysis of chlorophyll content of SAL area 2016 based on Ground check, to facilitate its spatio-temporal representation, presented in the form of thematic map (Figure 2). The overall fluctuation of chlorophyll a throughout 2016 is represented by graphs on the map (Figure 3).

The results of field measurements occur the optimality of chlorophyll-a during transitional season II, it is supported by the peak rainfall in 2016 in October reached $958 \mathrm{~mm}$ which is month the highest rainfall month in the last five years. The existence of ecological conditions of high rainfall, affect the high fluctuations of organic materials and quantity of chlorophyll- a. The increase of rainfall is proportional to the chlorophyll measurement data in the field and vice versa. The results of lands and field measurements ground check showed that the measurement of chlorophyll a in the east season is higher when compared to the west season. According to Nontji [16] the results of this study are in line with the results of research that occurred in the Banda Sea, where the occurrence of upwelling or lifting of water rich in organic material elements from the inner layer up to fertilize the surface layer, which occurred during the east season. While the mechanism of downwelling or the occurrence of water drowning of the surface on the deeper layers of water occurs in the west season. Furthermore, from the expedition Snellius II (1984-1985) which is a joint expedition Indonesia-Dutch. Expedition results also stated that in August there was an upwelling that caused increased water productivity, reflected by the value of phytoplankton chlorophyll ranged from $1.3 \mathrm{mg} / \mathrm{m}^{3}$. Conversely at the time of downwelling chlorophyll decreased to about $0.4 \mathrm{mg} / \mathrm{m}^{3}$. The effect of upwelling was evident throughout the southern waters of Java-Bali in August (east season) during upwelling, the phytoplankton was very fertile while in February (the western seasons) the abundance fell back.

The result of spatial analysis at research station (S) is known that the high chlorophyll a during the study occurred at (S1), (S5) and (S7), which is a station with characteristic of anthropogenic activity especially happened at transition season I, east season to season transition II. The diversity of anthropogenic activities contributes to the improvement of the organic elements of water supported by high rainfall and upwelling phenomenon. In according to the Panggabean [17] and Livingston [14] stated, rainy season occurs in the process of washing of organic material from the river mouth, mainly by the discharges of various anthropogenic activities resulting in the increase of organic material entering the coastal waters. Furthermore, phytoplankton is able to show tolerance to the condition of water instability, when an increase in organic materials. It is characterized by changes in species dominance, changes in community structure, biomass and high content of phytoplankton chlorophyll [21], [2]. 


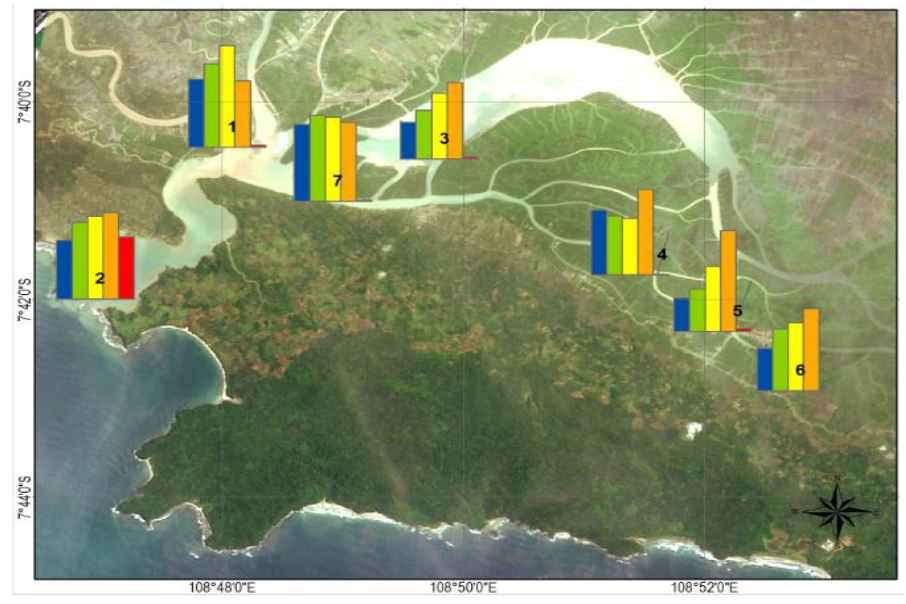

SCALE 1: 60.000

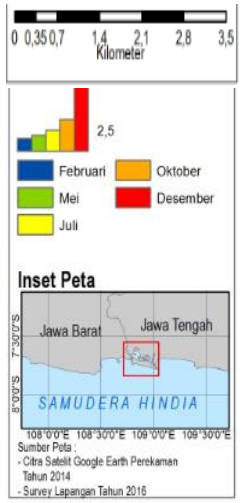

Fig. 3 Thematic map of chlorophyll-a during the sampling in 2016 with the approach of spatial and temporal

3.2 The accuracy of chlorophyll- a concentration between the result of Landsat satellite multitemporal imagery measurements and ground check in SAL area.

The results of ground chlorophyll measurements are used to verify the mapping results with satellite imagery. In this study (in 2016) the chlorophyll content of the SAL region was measured by both methods, using both landsat and ground (Ground check) satellites. The measurement results show that the accuracy is high, shown by the value of $r=$ 0.94 with the equation $\mathrm{y}=-30.07 \mathrm{x}^{2}+217.0 \mathrm{x}-387.09, \mathrm{R}^{2}=0.894$ (Figure.4). Based on data of characteristic, logarithmic regression model is polynomial with data on $\mathrm{X}$ axis (field) and $\mathrm{Y}$ (Landsat satellite image). From the results show a positive pattern, that the higher value of chlorophyll of field results is proportional to the high chlorophyll in the satellite image.

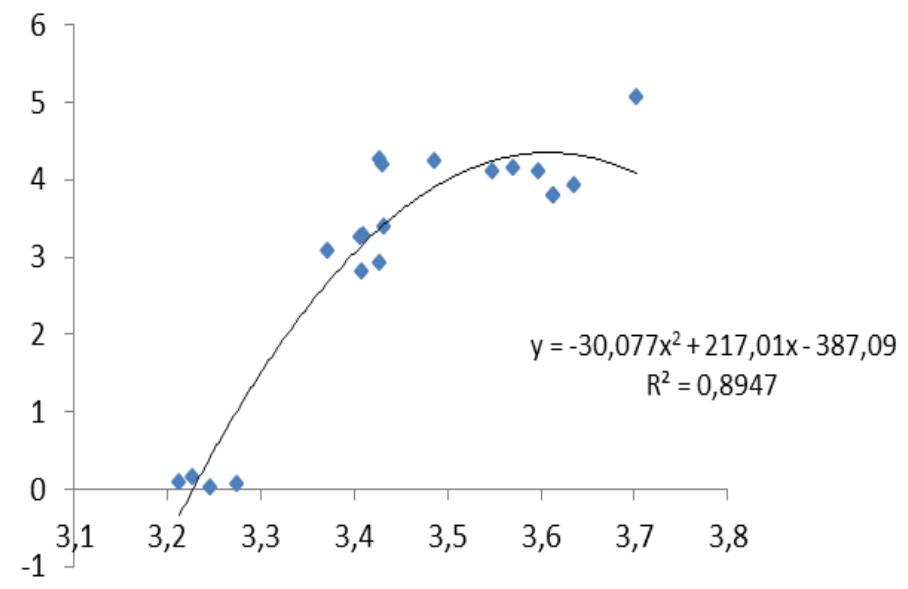

Fig. 4 Accurated result of Satellite Image of chlorophyll-a with measurements on the field in Segara anakan lagoon area 


\section{Conclusion}

SAL region is a dynamic water region, there is influence of natural and anthropogenic factors which subsequently contribute to the accumulation of organic matter. Supported by high rainfall and upwelling phenomenon result in fluctuation of chlorophyll content a. The high value of accuracy test on the obtained equation shows that the algorithm in the SAL area can be applied to obtain chlorophyll-a content data in the previous years, for example for 15 years back 2001-2015, with the support of chlorophyll-a landsat satellite image (Y) in that year. Application of remote sensing method using chlorophyll a satellite image can then be used for the preparation of management strategy of lagoon management by Local Government, related parties and community to maintain ecological stability of lagoon.

\section{References}

1. Ardli, E.R., and M. Wolff. Reg. Environmental Change. 9: 235-243 (2009)

2. Ayuningsih, M.S, I.B. Hendrart and P.W. Purnomo. Diponegoro Journal Of Maquares. Manajement Of Aquatic Resources. 3, 138-147 (2014).

3. Carolita, I, E. Parwati, B. Trisakti, T. Kartika dan G. Nugroho. 2005. MAPIN XIV Annual Scientific Meeting. Effective utilization of remote sensing for enhancing the welfare of the nation. Institute Teknologi Sepuluh Nopember, Surabaya

4. Coutinho, M.T; A. C. Brito; P. Pereira; A.S. Gonçalves and M.T Moita. Journal Estuarine, Coastal and Shelf Science. 110: 134-146 (2012)

5. Danoedoro, P. 2012. pp 159-366

6. Dewi, R., M. Zainuri., S.Anggoro., T.Winanto. Omni Akuatika Journal. 12, 144-150) (2016)

7. Dsikowitzky,L, I. Nordhaus, TC. Jennerjahn, P. Khrycheva, Y.Sivatharshan, E.Yuwono, J. Schwarzbauer. Marine Pollution Bulletin 62. 851-862 (2011)

8. Hatta, M. 2002. http://tumoutou.net/3_sem1_012/muh_hatta.htm. 1 April 2007.

9. Helmi, M.. Journal of Marine Science. FPIK. Diponegoro University. Semarang. (2006)

10. Herawati VE. Thesis. Diponegoro University. Semarang (2008)

11. Hutagalung HP, D. Setiapermana, SH. Riyono. P3O-LIPI (1997)

12. Jennerjahn, P. Holtermann., I. Pohlenga and B. Nasir. Research Institute University of Jenderal Soedirman. Purwokerto (2007)

13. Jennerjahn, B. Nasir, I. Pohlenga. Reg Environ Change 9:259-274 (2009)

14. Livingston, R.J. Marine Science Series Boca Raton. Printed in the United State of America. Pp 327 (2001)

15. Nontji, A. LIPI Press. Jakarta. 331Pp (2008)

16. Nuriya H, Z. Hidayah, W.A Nugraha. Marine Journal. 3 (1): 60-66( 2010)

17. Panggabean, L.M.G. Oseana. 19 (1):33-38 (1994)

18. Parslow, J.J. Hunter and A. Davidson. CSIRO Marine Research. Hobarth, Tasmania (2008) 
19. Pintado, J.G; M.M. Mena, G.G. Barberá; J. Albaladejo and V.M. Castillo. Science of the total environment. 373: 220-239 (2007)

20. Sidik, A., A. Agussalim, M. Rasyid Ridho. Maspari Journal. 7 (2): 25-32 (2015)

21. Vadrucci, M.R., E. Stanca., C. Mazzioti, N. Ungaro and A. Basset. Ecological Indicators. 34: 113-125 (2013)

22. Walpole. Pengantar Statistika. Jakarta: Gramedia Pustaka Utama (1995)

23. Yuwono, E; TC. Jennerjahn; I. Nordhaus; E.A. Riyanto; M.H. Sastranegara and R. Pribadi. Asian Journal of Water Environment Pollution. 4, no. 1, pp: 61-70 (2007) 